Authors' Copy as Accepted for Publication

Maria Kaparou (1) and Tony Bush (2)

(1) School of Education, The University of Nottingham Malaysia Campus, Malaysia

(2)School of Education, The University of Nottingham (Malaysia and UK), Nottingham UK

\title{
Instructional Leadership in Greek and English
}

\author{
Outstanding Schools
}

\begin{abstract}
This research paper examines instructional leadership in outstanding secondary schools within a centralised (Greece) and a partially decentralised (England) education context. Since the purpose of the study is exploratory, the researchers adopt a qualitative approach, employing a series of four qualitative case studies with the purpose of examining the impact of instructional leadership on student learning, teachers' professional growth and school improvement, using the interpretivist paradigm. Semi-structured interviews with various data sets (stakeholders) within and outside the school, observation of leadership practices and meetings, and scrutiny of relevant macro and micro policy documents are employed to enhance methodological and respondent triangulation.
\end{abstract}

Recognising that instructional leadership is not confined to the principals' leadership domain, a sense of shared and distributed leadership prevails in schools, while its implementation is inevitably linked to system constraints. The findings from the Greek schools link to the official expectations that principals operate as administrative rather than instructional leaders, while an unofficial instructional 'teacher leadership' culture suggests potential for reconsidering leadership in Greek state schools. In contrast, the decentralization of school activities creates the platform for the emergence of shared and distributed leadership within the English context, where school actors enact direct and indirect instructional leadership roles. This cross-country comparative study demonstrates theoretical significance in its focus on the collaborative and reciprocal nature of instructional leadership, while its empirical contribution lies in generating new knowledge on how instructional leadership is contextually bounded.

\section{Keywords}

instructional leadership, outstanding schools, school improvement, England, Greece, monitoring, mentoring, coaching, professional development 


\section{Introduction}

Research and literature from different international contexts shows that there are two key influences on student learning: classroom practice and leadership (e.g. OECD, 2005; Leithwood and Jantzi, 2008; Robinson et al., 2008; Hallinger and Heck, 2011). These influences suggest that an instructional leadership focus is an important pathway for teachers' professional improvement and student learning. Policy makers' emerging emphasis on improving teaching and learning led to an interest in the concept of principal instructional leadership in the USA (e.g., Leithwood and Montgomery, 1982; Hallinger and Murphy, 1986; Marcoulides and Heck, 1992; Hallinger and Heck, 1996), and England (e.g., Day et al., 2001; Southworth, 2002; MacBeath and Swaffield, 2008). However, there has been very little discussion in Greece about how leadership is conceptualized by school practitioners and whether leadership contributes to school improvement (e.g. Demertzi et al., 2009).

Dimmock and Walker $(1998,2000)$ highlight the importance of comparative studies of educational leadership and management, as there is growing awareness of the impact of globalisation on educational policy and practice (Rui, 2007). However, given that 'context matters' (Crossley and Watson, 2004: 6), this study provides significant new evidence on the operation of instructional leadership in two dissimilar countries. 
Setting the policy landscape into context was an important first step when the researchers constructed the architecture for this comparative study. In the English 'relatively decentralised education system' (Day et al., 2007: 3), it is highlighted that the work of headteachers- and, therefore, their staff- is subject to a range of policy imperatives which, depending on perspective, act as 'drivers', encouraging schools to improve through the challenges they offer [...]. (Day et al., 2008: 11)

This statement shows the mediating and moderating role of headteachers, to create the conditions in which teachers perform in order to improve learning outcomes. Raising standards in teaching and learning, improving teaching quality, and giving more autonomy to headteachers and teachers, were among the major intentions in 'The Importance of Teaching' White Paper (DfE, 2010) and subsequent legislation (the Education Act 2011).

The administration of education in the centralised Greek context is conducted hierarchically, and the centralisation of policy and top-down decision-making remain key features of the Greek educational system (e.g. Saitis, 2002; Kaparou and Bush, 2007; 2015). Despite the Greek headteachers' predominant administrative role, there are limited opportunities for headteachers to enact aspects of instructional leadership (Educational Law 1566/85; Ministerial Decision 353.1/324/105657/ $1 / 2002$ ).

The aim of this paper is to present empirical evidence of the nature of instructional leadership (IL) in four outstanding secondary schools within a cross-country comparative context. The paper seeks to answer three research questions:

a) What is the nature of instructional leadership in English outstanding secondary schools?

b) What is the nature of instructional leadership in Greek outstanding secondary schools? 
c) How do approaches to instructional leadership differ between a centralised system (Greece) and a partially de-centralised system (England)?

\section{Literature Review}

Perspectives on instructional leadership

Instructional leadership has been identified as one of the most significant leadership concepts in English speaking countries (notably UK, North America, Australia, New Zealand). International studies (e.g. Hallinger and Heck, 1997; Southworth, 2002; Timperley, 2006; Pansiri, 2008; Bush and Glover, 2009) reinforce that instructional leadership is highly concerned with the 'technical core of education'. Leithwood et al. (1999: 8) argue that 'instructional leadership [...] typically assumes that the critical focus for attention by leaders is the behaviour of teachers as they engage in activities directly affecting the growth of students.' Elmore's (2000) definition takes teaching improvement as a focus with a view to improving learner outcomes. The contribution of leadership to school improvement is widely acknowledged and the research literature shows that high quality academic and/or professional learning requires an instructional leadership orientation (e.g. Leithwood et al., 2006; Hallinger and Heck, 2010; Sammons et al., 2011).

Hallinger (2009:1) notes that 'instructional leadership has recently reincarnated as a global phenomenon in the form of "leadership for learning", which is conceived as a more distributed and/or shared school leadership paradigm for $21^{\text {st }}$ century school contexts, in contrast to earlier notions which emphasized a solo model of instructional leadership (Barth, 1990; Day et al., 2001). A developing understanding of leadership for learning has been highlighted by Swaffield and MacBeath (2009), 
based on the outcomes of the 'Leadership for Learning Project' (2002-2005), to be discussed later. This notion provides 'a wider perspective of who might exercise instructional leadership' (Bush, 2014: 3), while Marks and Printy’s (2003) study confirms the shift towards a shared instructional leadership dimension which describes the creation of an environment for building staff instructional and leadership capabilities to improve student learning.

The conceptual framework which informs this research is instructional leadership (IL), which involves a number of leadership activities that create an effective principal-teacher interaction with the intention to improve the quality of teaching and learning. The knowledge base of IL is captured under practices that affect learning, as adapted from Hallinger and Murphy's (1985) three dimensions of the instructional leadership construct -indicating school mission, curriculum, teachers' professional growth- and Southworth's (2002) three strategies which are powerful in influencing teacher's practice within learning-centred leadership: modelling, monitoring, and mentoring. Within this instructional perspective, learning refers to student progress and teachers' growth, while the leaders' contribution, via teachers' professional learning, is a hallmark of school improvement. The collective work of prominent studies (Hallinger and Murphy, 1985; Southworth, 2002) of IL led to the conceptualisation of instructional leadership as encompassing the following dimensions:

- Vision for Learning

- Curriculum management

- Evaluation of students results for a systematic monitoring of student progress

- Monitoring teachers' performance

- Mentoring and coaching 
- Modelling

- Continuing professional development.

The underlying key components of IL are used for analysing the research case studies, since leaders' instructional engagement with these strategies facilitates learning, which is at the heart of IL. Generating knowledge grounded in the aforementioned dimensions provides a medium to obtain a fresh conceptual understanding on instructional leadership theory and practice.

\section{International overviews}

Within the international context, the corollary of various projects, such as the OECD (2009) Teaching and Learning International Survey (TALIS) and the Leadership Improvement for Student Achievement (LISA, 2009) is that instructional leadership constitutes one of the most predominant leadership styles. In the international Leadership for Learning (LfL) Carpe Vitam Project (2002-2005) within 24 different schools and policy contexts, leadership within the LfL framework is shared and accountable:

not by a few people in formal positions of power controlling and directing many others, but by actions taken by all members of a community in the everyday flow of activity. (MacBeath and Swaffield, 2008: 1)

Although cultural differences may lead to diverse findings, the LfL project showed some common dimensions of leadership, learning and their interrelationship.

\section{Instructional leadership in England}

Instructional leadership was 'one of the National College for School Leadership's (NCSL) ten leadership propositions' (Bush and Middlewood, 2013: 16) in its 2001 
Leadership Development Framework, underpinning effective learning, while stressing the critical role of principals in influencing the behaviour of staff to engage with activities which affect the quality of teaching and learning. A systematic review of the literature on educational leadership shows that instructional leadership remains under-researched in England (Hopkins et al., 1997; Southworth, 2002). Hopkins et al.'s (1997) school improvement project in England advocated a prominent role for instructional leaders in enhancing organisational capacity and having an impact on student achievement and learning. In Southworth's (2002) research in small primary schools the strong connection between teaching, students' growth and teachers' professional learning is illuminated, despite the lack of clarity about IL's differentiation by context, gender or school size.

There is an emerging literature on leadership for learning (e.g. MacBeath and Swaffield, 2008) while several studies (e.g. Earley et al., 2002; Day et al., 2007; Higham et al., 2007) stress school leaders' involvement in practices related to IL. Dimmock (2012) argues that headteachers' instructional leadership is constrained by government policy priorities, as measured by league tables and inspection regimes. What emerges from Day et al.'s (2007), and Sammons et al.'s (2011) research is the direct and indirect effects of school leadership practices in English primary and secondary schools, which also appear to influence academic results. These findings are in line with Leithwood et al.'s (2006) widely cited study on the impact of leadership on student outcomes.

Since it sets expectations about leadership enactment to improve teaching and learning in England, evidence from Ofsted's (2009) research in outstanding schools recognizes aspects of learning-centred leadership. The findings from 12 outstanding 
schools in England (Ofsted, 2009) have certain similarities with Macfarlane and Woods's (2011) results within outstanding schools in London. For instance, managing the curriculum through enhancing creativity in the curriculum and personalized learning, as well as monitoring students' progress, are the catalysts for change. The outcomes of the leadership development programme Good To Great (G2G), set up by the London Leadership Strategy in 2008 and the Going For Great (G4G, 2010), added significantly to the empirical literature through the 'Eight Pillars of Greatness' (Macfarlane and Woods, 2010: 17) which are related to instructional leadership.

\section{Instructional leadership in Greece}

Much of the Greek literature is what Muijs (2011: 116) has

called "position papers", [...],[-] articles that are neither based on empirical research nor systematic literature reviews, but contain position statements on factors such as ethical leadership or introduce new leadership concepts.

There are few published studies of instructional leadership (Kaparou and Bush, 2015), in Greek or English, although there are a few papers viewing school management from headteachers' perspectives (e.g. Athanasoula- Reppa and Lazaridou, 2008), the principal's role and its contribution to the school's effectiveness (e.g. Lainas, 2004; Stravakou, 2003), and effective schools (e.g. Pashiardis and Pashiardis, 2000). Christodoulou's (2007) study of 20 headteachers' perceptions of school leadership and management in Greek schools confirms Saitis and Eliophotou-Menon's (2004) findings, which stress that the authoritarian and managerial style of leadership emanates from the Greek bureaucratic educational system. Hallinger and Lee's (2014) study in Thailand confirms the difficulty of changing the headteacher's managerial role to an instructional leadership profile within a centralised system. In contrast, the findings in Pashiardis and Savvides 
(2011) International Successful School Principalship Project in Cyprus show that headteachers' learning-centred leadership assists students' academic performance. Brauckmann and Schwarz's (2014) survey of Cypriot headteachers identifies a variety of school leader types (challenger, optimist, sceptic, opportunist) which act differently towards the effects of centralisation, autonomy and the interpretation of 'state-driven reforms' (p.824).

Whilst three Greek schools have participated in the Carpe Vitam LfL Project, the main lesson was that 'educational leadership is in its infancy' (Bagakis, 2007: 270). MacBeath's (2006: 43) argument may explain the complexities of school change and improvement within a heavily centralized system:

In regimes with a deeply entrenched addiction to hierarchy, this presented a leadership dilemma. In Greek schools, principals spoke of constantly bumping up against a tradition that attached specific and inflexible roles to the head teacher, teachers, parents, and the school custodian.

Demertzi et al. (2009: 303) point out that, 'given the structure of the Greek education system, we found no evidence of the distribution of leadership through an established system or the attribution of shared roles', despite very limited evidence of teachers' experimentation with 'cooperative models of learning and leadership' (ibid: 305). Unsurprisingly, though, Biniari (2012: 214) confirms that norms of professional collaboration have not been formalised in Greek state schools, 'possibly due to the lack of the appropriate organisational climate' However, evidence in outstanding schools in Athens shows 'IL is not confined to the principals [and this] creates space for a sense of shared leadership' (Kaparou and Bush, 2015: 337).

\section{Methodology}


A qualitative multiple case design allowed detailed data to be collected and compared, grounded in the meanings participants give within two dissimilar educational systems, using the interpretivist paradigm (Creswell, 2003) for the understanding of different 'socially constructed realities' (Blaikie, 2000: 25). Treating each school as an individual case study in a particular context created a platform for presenting rich data of real-life events (Yin, 2009) generated from each case. The cross-case analysis of the four research case studies provided the potential for analytic generalization (e.g. Bassey, 2007).

\section{Sampling}

\section{$\underline{\text { School sampling }}$}

The researchers opted for a purposive sample of outstanding secondary schools. Since there is no official performance measurement mechanism in the Greek setting, the researchers used the national exam results as a proxy for 'high performance', as student results are considered to be a variable associated with effective schools. However, good outcomes may be influenced by the contextual variable of private tuition. Scrutinizing the confidential list of schools portraying school results at a national level, provided only by one Directorate of Secondary Education, the two researched schools comprise the best (school D) achieved and the second best (school C) of the 46 state secondary schools in one district of Attiki.

The English schools were chosen from those with 'outstanding' grades overall in the most recent OFSTED Inspection Reports (in 2010 for school A; in 2011 for school B) within central England. In addition, the 2010 examination results -which placed them in the top 200 schools in the country in terms of GCSE examination results- shaped the high performing school status that the researchers set as a criterion for sampling. 
According to the school performance tables published by the Department for Education (http://www.education.gov.uk/schools/performance/archive/schools 10.shtml), school A has the highest GCSE results (79\%) in the region, while school B results show an increase in the percentage of students achieving 5+A*-C GCSE (including English and Maths) (see Table 1).

\begin{tabular}{|c|c|c|c|c|}
\hline Acad. Year & $\begin{array}{c}\text { Case Study } \\
\text { School A }\end{array}$ & $\begin{array}{c}\text { Case Study } \\
\text { School B }\end{array}$ & LA & England \\
\hline $\mathbf{2 0 0 9}$ & $79 \%$ & $64 \%$ & $48 \%$ & $50 \%$ \\
\hline $\mathbf{2 0 1 0}$ & $79 \%$ & $68 \%$ & $52 \%$ & $54 \%$ \\
\hline
\end{tabular}

Table 1: Percentage of students achieving 5+A*-C (and equivalent) including English and Maths GCSEs

\section{Participants' sampling}

The matched purposive samples (Brundrett and Rhodes, 2014) comprised: the headteacher, one deputy head in each school, one assistant head for teaching and learning (only in school B), two external senior subject advisers (for Greece), two middle leaders (for England), the two most experienced subject teachers (for Greece), the nearest equivalents to subject leaders and eight subject teachers of languages and mathematics (core modules for the national exams) in each school, to provide an overview of managing teaching and learning and to establish whether and how they are responsible for implementing instructional leadership.

\section{Methods}

The researchers adopted a mixed methods approach to obtain greater credibility for the results, combining several methods to answer the same research questions (e.g. Bryman, 2008).

\section{$\underline{\text { Documents }}$}


In England, official published documents, such as recent Ofsted Inspection Reports and GCSE league tables, in addition to school level documents, were scrutinised, but not treated as objectively representative of the social context (Cortazzi, 2002). For the Greek cases, external documents such as official statistics (of the Panhellenic examination results, the Educational Law 1304/82), and subject advisers' pedagogical documents, were critically analysed in order to cross check data derived from schools teachers' committee pedagogical meetings' minutes.

\section{$\underline{\text { Interviews }}$}

Semi-structured interviews, with a stratified sample of 51 stakeholders, provided the basis for respondent triangulation (Perakyla, 2008) and reduced the danger of bias in analysing participants' responses. Conducting interviews with the different data sets, as explained in sampling section, played an important role in cross- checking the validity of the findings.

\section{Observations}

'To completely understand instructional leadership as a practice, we need to understand how leaders do what they do as well as the role of context in shaping what they do.' (Coldren and Spillane, 2007: 372) Semi-structured observations took place through shadowing the headteachers (the deputy head in school A) to record the nature and frequency of their IL activities. Observations of a leadership team meeting (in England), a leadership development day (only in school B), and a school teachers' association pedagogic meeting (in Greece), gave a snapshot of leadership activity within schools.

\section{Data Analysis}


The comparative base of analysis within two contrasting educational systems is captured within three vertical levels, demonstrating the interplays between policy, educational actors and IL practices. This three-layer comparative framework for analysis led the researchers to synthesise each country's contextual data analysis, prior to drawing conclusions based on a comparative analysis of the two data sets. Comparing data sets involved three tiers of analysis. The first stage involved two parallel clusters (in terms of country) of schools, in which codes were categorized based on the school contextual situation (within the school coding) across different data sets. The second stage consists of clusters of codes which have been recognized as meaningful in both schools in the same country, while this coding entails the emergence of a discussion of complexities, interactions and levels of differentiation in two different school in the same country (between 2 schools). The third stage highlights the common and different themes, which emerged from a cross-country comparative analysis of data (Fitzgerald, 2007).

\section{Findings and Discussion}

In England, school A is a large faith-based secondary (11-18) school, with over 1400 pupils and 140 teaching and support staff in central England. School B is a large (over 1500 students and 117 teachers) National Support School with an Executive Headteacher, supporting two low-performing secondary schools. School C is a medium-sized (391 students) secondary school in a suburb of Athens with high socioeconomic status and school D has 439 enrolled students. The latter's distinctive nature is that it is a model/experimental school in which staff teaching commitments are decreased due to its pilot nature. 
The next sections provide a synthesis of the data and literature. Several researchers (e.g. Walker and Dimmock, 2002; Leithwood et al., 1999) stress the contextualized nature of leadership. The current research also supports the need for developing contextually bounded school leadership and management theories within centralized and decentralized education systems. The vertical and hierarchical development of leadership in the centralised Greek system is highlighted in contrast to a pattern of vertical and horizontal distribution of leadership responsibilities in the devolved English system. The degree of centralization and decentralization across the two systems strongly influenced the four case studies, in terms of system and organizational policy, especially in respect of school leaders' influence on teaching and learning practices. However, emerging aspects related to 'functional centralisation and decentralisation, ${ }^{1}$ are not the only factors which suggest diversity in results.

Given that 'outstanding leadership is exquisitely sensitive to the context in which it is exercised' (Leithwood et al., 1999: 4), the following contextual factors are related to the organizational structure and policy, creating the platform for a variation in leadership for learning practices in the four case study schools:

- the school size,

- $\quad$ status- the Academy status for both English schools, along with the National Support School Status of school B and the experimental/pilot type of school D allow a greater discretion for autonomy in the teaching and learning process,

- the socio-economic background of students in school C,

\footnotetext{
1 'Functional centralisation and decentralisation implies that the similar activities or functions of an organisation take place in one division or are distributed. (Ferreira et al., 2009: 348)
} 
- aspects of centralization and school autonomy, in terms of leaders' authority to go beyond the political directives and create unofficial mechanisms to maintain a strong focus on teaching and learning,

- the organisational structure, e.g. the extended leadership team in both English schools which accentuates the distribution of authority, for learning.

Certain structures appear to emerge across the systems, where policies for learning and teaching are approached differently. In addition, the vertical and hierarchical development of leadership in medium-sized schools in the centralised Greek system is highlighted in contrast to a pattern of vertical and horizontal distribution of leadership responsibilities in the devolved English system, which varied considerably regarding the extent of autonomy for schools and teachers.

\section{Vision for Learning}

Despite the differences between the two systems, notably in respect of the degree of centralization, there is a convergence of findings across the four case study schools in respect of the results-driven focus. This is perhaps an inevitable outcome of both the Greek and English systems, with top-down policy-making, and a strong inspection regime, respectively. The English faculty leader in school B states that 'teachers know what the vision is -outstanding results- and they live and breathe it'. Exam results are a crucial factor for measuring schools' effectiveness and in maintaining accountability to the central authorities, as also noted by Robinson et al. (2008) and Leithwood et al. (2006).

In contrast to the English schools, where the vision for learning has been an official expectation, as described in the 2010 White Paper, this is not perceived to be the case 
in the Greek context, despite its centralized nature, which would be expected to extol a pre-determined government vision. In both countries, however, there is a hierarchical element to vision setting with external bodies strongly influencing the results-oriented focus. The degree to which vision-building is shared differs and there is greater evidence of collaborative vision building in the English secondary schools in comparison to the top down approach -where vision is merely expected to be articulated in practice - in the more centralised setting of Greece. The problematic nature of agreeing on an official school-based vision, within the Greek context, seems to emanate from the absence of a systematic monitoring of students' needs, insufficient involvement of the teachers in the process and the predominant role of Greek headteachers in cascading the government vision to the teaching staff, with limited flexibility to make individual school vision permeable and adaptable. Demertzi et al.'s (2009: 305) study confirms the limited scope for headteachers to create a vision 'that will challenge stagnation'.

Similarly to Bezzina's (2005) argument in relation to the Maltese hierarchical and centralised system, '[t]he move towards decentralisation has been sporadic, fragmented [and] incoherent'. The spirit of the hierarchical direction of vision, with elements of shared ownership, as evident in the decentralized and devolved English model, seems to be closer to the Norwegian case (Møller, 2009) than the Greek one, while the devolution of power seems to be under the umbrella of building consensus and collaboration in developing the vision (ibid: 262).

\section{Curriculum Management}

One important similarity between the English and Greek case studies is the hierarchical engagement in curriculum development as a corollary of the tightly 
prescribed national curriculum in both contexts. While both countries operate a national curriculum, there is more scope for English school leaders, especially in high performing schools, to modify it to meet the specific needs of their students. The headteachers in the two English schools empowered their instructional teams to create viable curriculum approaches to school improvement. An important theme emerging through interviews is personalizing students' learning; 'building the curriculum around students rather than try to fit them where we think they should go' (school B maths line manager).

In Greece, however, both subject advisers agreed they are part of a hierarchical structure concerning the management of curriculum, where the Greek specialist stressed the value of advisers' monitoring teaching materials, while the maths adviser states that 'we are not allowed to make suggestions to the heart of the curriculum structure.' In contrast to Ferreira et al.'s (2009: 350) point about 'greater simplification and standardisation of work processes', evidence from both Greek schools shows that it may not act as an advantage of the centralisation of administrative activities. The aspect of centralisation which suggests pressure to follow the national curriculum guidelines and specifications, is likely to be disputed. Pashiardis et al. (2004) argue that too much centralisation can affect the system negatively.

However, evidence reveals that teachers' tendency to resist standardisation in curriculum management has led to teachers' empowerment, which mainly lies within a tightly constrained synergy of collaborative 'groups which discuss necessary changes due to system's inefficiency', as school B's deputy head stated. Similarly, this happens 'sometimes in collaboration with other teachers at the same grade level.' 
(Printy, 2008: 198) This echoes Spillane et al.'s (2003: 536) findings where 'leadership for instruction involved multiple people, those in formal leadership positions and those who took on informal leadership responsibilities.'

\section{$\underline{\text { Evaluation of student results }}$}

The research findings show that the English school leaders systematically monitor student results, and provide personalized interventions, confirming Ofsted's (2009) review of outstanding schools. Given that reviewing students' progress is an overwhelmingly teacher-centred role in Greece, it is unsurprising to view teachers as a more direct force for school improvement, as teacher leaders. Other differences include the nature of monitoring and the intervention strategies employed. In England, unlike Greece, monitoring student achievement has been conceived as a widely distributed activity where school actors, at different levels, examine learners' outcomes and develop effective teams to create interventions.

Another aspect of differentiation relates to the strategies that schools devise with the purpose of establishing learning-centred improvement targets. The English school leaders' strategic approach to intervention contrasts with the absence of any official Greek mechanism to develop school-based strategies. School management systems may be similar across Greek schools whereas decision making about teaching and learning may be fluid, subject to schools' discretion to work outside government prescriptions. The era of high accountability in English schools may have led them to develop a systematic context-based strategic approach to address student underperformance. In contrast, snapshot mechanisms, characterised by sporadic and inconsistent practices, are evident in Greece, due to the lack of official support 
mechanisms for students, mainly due to opposition from the teachers' union.

However, all participants agree with school $\mathrm{C}$ head that:

none of the supporting measures for improving students' learning, such as the after school additional sessions, are still provided by the Ministry. The current educational system, which does not provide any additional support for students in state schools, forced them to private tutorials and tuition centres, although teachers provide students with some additional academic support, during the time that they are assigned to have administrative responsibilities.

The maths' subject adviser stressed the lack of official intervention mechanisms within Greek state schools, but he says that 'it depends on the sensibility of the teacher if they will devote more time with their students'.

\section{Monitoring teachers' performance}

The data from the English schools show that monitoring classroom teaching contributes to school improvement, supporting Robinson et al.'s (2008) conclusion that leaders' involvement in classrooms helps to improve teaching programmes. School A's deputy head ensures that the head of departments (HoDs) exercise learning-centred leadership to improve their staff's professional capacity, in order to sustain outstanding areas and develop group dynamics for improvement. Similarly, the deputy head of school B stressed the judgemental and developmental procedures to enhance teachers' performance.

In Greece, the maths' subject adviser says that the teachers' union refusal to accept any form of teachers' monitoring could be an obstacle to the professional development of teachers.

Assuming that a headteacher or adviser says I want to attend your class in order to evaluate your performance, this cannot happen. In Greece that would give rise to a storm of protest and there would be a general outcry from OLME's side (Greek Federation of State School Teachers of Secondary Education) etc. Those who lead in politics know well that evaluation is not implemented in Greece (maths school adviser). 
All teachers' views are similar to school C's deputy head's perception that:

neither the headteacher nor the subject advisers can get into the class and stand there as a scarecrow for students so that the teacher can work better. The trade union does not give its consent to that. You may make fun of it, but, in my 14-year experience in schools, I have seen a subject adviser in the school's premises only once, who visited due to a problem, not because s/he wanted to discuss with us, or support.

Although teachers' evaluation is implied by the law (Educational Law 2525/97), it is not evaluated within the Greek state school context and 'observation is not perceived as a mechanism for improvement' (Kaparou and Bush, 2015: 332). This resistance to policy enactment, driven by the Teachers' Union, may be related to the nature of evaluation and the evaluators' competence. The Greek case contradicts Fitzgerald and Gunter's (2011:90) argument that:

[a]lthough there has been an attempt by teachers and policy activists to resist and reinterpret policy imperatives, there does not appear to have been any large-scale and collective resistance. It might well be the case that some form of universal response is not possible given the unique contextual environments across nation-states.

The contrasting perceptions of monitoring across the two countries: 'the key cornerstone of what you do' (school B senior deputy head) and 'an authoritative threat to teachers' work' (school D chemistry teacher), present stark systemic and cultural differences towards monitoring. Significant contextual differences across schools are the outcome of a relatively high degree of autonomy at school level in England, stressing the socially constructed nature of leadership (e.g., Leithwood et al., 1999). However, autonomy is subject to governance influence under the "policy architecture within which [...] schools [work]' (Bottery, 2007: 95).

\section{Mentoring and Coaching}

Mentoring and coaching are used differently in the two countries. While mentoring is mainly implemented for newly appointed teachers in Greece, there is a growing 
emphasis on informal peer-professional discussions. However, the school D headteacher explains the difficulty in encouraging teachers to share their good teaching practices with colleagues:

The fact that Greek teachers' performance has not been evaluated, for many years, makes many teachers think that they are the Kings in their Kingdom. It's not easy to encourage teachers to coach each other, especially coaching those who face teaching difficulties. However, what I do is that I ask a teacher, who is respectful and knows how to approach colleagues, to help a teacher.

The limited role of the Greek senior leaders contrasts with the extensive involvement of leaders in official mentoring and coaching in the English schools. Coaching has been conceived as a delegated pedagogical method for the improvement of learning, implemented by senior, middle and subject teachers in both English schools. A growing emphasis on reflective practice and collaboration in English schools may be influenced by the accountability regime, while peer-coaching, especially through the learning and teaching group, has been conceived as a mechanism to foster teachers' professional performance, through 'learning-centred talk' (MacBeath and Townsend, 2011: 9).

\section{Modelling}

The Greek leaders had limited opportunities to model good teaching practice, in contrast to the more active role of English school leaders. Despite the official modelling role of Greek subject advisers, teachers are critical about their role:

Subject advisers' modeling is 'a frame-up theatre... like a game'. There is no point in discussing the subject advisers' role in that because they are like the ornaments we have in our house. They are figureheads. (School D most experienced maths teacher)

An alternative to modelling is peer-sharing of good practices, which has been a common thread among the schools in the two contrasting systems. This links to 
notions of reciprocal learning, based on dialogue, engagement, and reflection upon teaching, within a peer-modelling process. School B's English HoD says:

we do try modeling for each other. As a faculty, when we have meetings we always have learning and teaching on the agenda and talk about some good practice whenever possible. Also, if you go to our hub in our lunch time, you hear people talking about teaching and learning and that's just lovely.

There is a shift in the instructional teaching paradigm towards a more reciprocal learning experience. This argument reinforces Vygotsky's (1978) theory of learning which enhances the reciprocal experience for students and learners, while acting and interacting in shared experiences between teachers as instructors and teachers as learners.

\section{Continuing professional development (CPD)}

In both countries, there are opportunities for professional development with the purpose of encouraging pedagogical improvement. However, in Greece, this was not regarded positively due to the perception that they are not linked to classroom practice, but rather provide generic blueprints of teaching, hence marginalising theory from practice. The majority of science teachers in school D criticize these training seminars, since they do not contribute to their knowledge-building:

There is no way that I'll miss my class in order to go to our subject adviser's seminars or EKFE [Laboratory Centre of Physical Sciences] seminars. Whenever I've attended these seminars, they are always similar. We don't hear anything interesting. All presentations are good in theory but not applicable in practice. So, why should I go? (physics teacher)

In the English context, a similar debate about whether external provision is highly connected to practice, notably in school $\mathrm{B}$, is highlighted. In addition, Gravani and John's (2005) study on in-service professional development programme in Greece 
shows the necessity for teachers' involvement in decisions related to programme's content and their engagement in active dialogues.

A distinctive feature of the English system is the establishment of in-house training, linked to the national strategy (e.g. NCSL 2004) for teacher development. Whilst the English cases support the establishment of contextualised CPD, they also value a school-based learning repertoire for the encouragement of personalized capacity building. This is not the case within the centralised Greek context, despite the attempts of the model school (D) to develop professional development opportunities for their teachers.

\section{Conclusion}

This cross-country comparative study highlights the contrast between a highly centralised and a relatively decentralised context in influencing school improvement practices. There was evidence from the English schools and the literature that there is a shift from hierarchical to horizontal forms of instructional leadership in high performing schools in England whereas the centralised policy imperatives in Greece do not allow the flexibility to encourage shared leadership for learning. In addition, another issue of differentiation is encapsulated in the nature of strategies adopted and the extent of implementation, subject to contextual differences.

The remaining sections of the conclusion show how the research questions were answered.

What is the nature of instructional leadership in English outstanding secondary schools? 
Given the high level of accountability in English schools, the strategies adopted have a shared instructional leadership orientation within a formal hierarchical framework. A distinctive feature of IL in the English schools, notably in school B, is a tendency towards personalised teaching and learning, and this may link to the desire to sustain their outstanding status. Peer-learning, mainly through mentoring and coaching, fuel professional reflective dialogues. However, the case study schools both feature a constrained collaborative pattern, limited both by central government prescription and the dominant role of the SLT, which raises issues about the nature of shared instructional leadership.

What is the nature of instructional leadership in Greek outstanding secondary schools?

Principals and subject advisers' instructional leadership is constrained by their government bounded roles and teacher leadership is occupying the limited space. A hierarchical delegation of actions is expected in a centralised system, but, in both researched schools, all teachers had the same modest opportunities to enact shared instructional leadership. Teachers established informal shared leadership practices to ensure that pedagogical initiatives are put in place to support the development of the 'lost purpose of Greek state schools, which must be the school as the main tool for student achievements' (school C maths teacher).

How do approaches to instructional leadership differ between a centralised system (Greece) and a partially de-centralised system (England)? 
The authors' research evidence confirms that leadership execution varies markedly by context (e.g. Leithwood and Riehl, 2003), while the similarities arise from implementing government policy. This also raises questions about the boundaries of, and opportunities for, leadership enactment in centralised and relatively decentralised educational contexts. However, leadership is not constrained totally by centralisation, as there were elements of informal instructional leadership practices in the Greek schools. Within the centralised Greek context, an informal horizontal and limited instructional leadership pattern may be the outcome of a tightly prescribed organizational system whereas, in the relatively decentralised English context, a hierarchically shared and distributed model links to central government expectations for outstanding schools.

However, given that leadership actions are spread, despite the accountability regime in England and the centralised norms in Greece, the main contrast was between formal enactment of leadership in England and informal teacher-led instructional leadership in Greece, since the subject advisers' official roles are rarely enacted. Another key distinction relates to attitudes to performance evaluation. In Greek schools, there is resistance to activating this practice, because it is perceived as surveillance, whereas, in the English contexts, this was seen as a necessary strategy for teachers' pedagogical improvement, even though the inspection process itself was often unwelcome.

Developing teachers' learning improvement and leadership capacity have been striking examples of co-constructed instructional leadership in the two outstanding English secondary schools. This links to the notion of shared leadership in the English schools, in contrast to those in Greece. It seems that the tightly prescribed 
domains of influence are for Greek principals' domain to be the whole school while teachers' domain remains their classroom. This is less evident in the English partially decentralized context, which allows more scope for initiative and a collaborative inhouse learning community.

\section{References}

Athanasoula-Reppa, A. and A. Lazaridou (2008) 'Requirements, roles, and challenges of the principalship in Greece and Cyprus: newly appointed principals' views', European Education, 40(3): 65-88.

Bagakis, G. (2007) 'Reviewing the Greek educational changes after the Carpe Vitam participation. Leadership for Learning' in G. Bagakis, K. Demertzi and T. Stamatis (eds), A School Learns: Development and School Self-evaluation within the Carpe Vitam: Leadership for Learning Project, Athens Greece: Livanis Publications, 263-273 (in Greek).

Barth, R. (1990) Improving Schools from within, San Francisco: Jossey-Bass.

Bassey, M. (2007) 'Case studies', in A. Briggs and M. Coleman (eds), Research Methods in Educational Leadership and Management, 2nd edn., London: Sage, 142-155.

Bezzina, C. (2000) 'Educational leadership for twenty-first century Malta: breaking the bonds of dependency', International Journal of Educational Management, 14(7): 299-307.

Biniari, L. (2012) The Development of School Self-evaluation Tools for Leadership for Learning. A Portrait and Profile, PhD thesis, Greece: The University of Patras (in Greek).

Blaikie, N. (2000) Designing Social Research: The Logic of Anticipation, Cambridge: Polity Press.

Bottery, M. (2007) 'Reports from the front line: English headteachers' work in an era of practice centralization', Educational Management Administration \& Leadership, 35(1): 89-110.

Brauckmann, S. and Schwarz, A. (2014) 'Autonomous leadership and a centralised school system', International Journal of Educational Management, 28(7): 823841.

Brundrett, M. and Rhodes, C. (2014) Researching Educational Leadership and Management, London: SAGE Publications Ltd.

Bryman, A. (2008) Social Research Methods, New York: Oxford University Press.

Bush, T. (2014) 'Instructional leadership in centralised contexts: rhetoric or reality?', Educational Management Administration \& Leadership, 42(1): 3-5.

Bush, T. and Glover, D. (2009) 'Managing teaching and learning: a concept paper', Johannesburg: Matthew Goniwe School of Leadership and Governance (MGSLG).

Bush, T. and Middlewood, D. (2013) Leading and Managing People in Education, London: SAGE Publications.

Christodoulou, A. (2007) School management from the principal's perspective: selfconception of the principal's role, MA dissertation, Greece: University of Thessaloniki (in Greek). 
Coldren, A. F. and Spillane, J. P. (2007) 'Making connections to teaching practice: the role of boundary practices in instructional leadership', Educational Policy, 21(2): 369-396.

Cortazzi, M. (2002) 'Analysing narratives and documents', in M. Coleman and A.R.J. Briggs (eds), Research Methods in Educational Leadership and Management, London: SAGE, 196-.212.

Creswell, J. W. (2003) Research Design: Qualitative, Quantitative, and Mixed Methods Approaches, London: Sage.

Crossley, M. and Watson, K. (2004) Comparative and International Research in Education: Globalisation, Context and Difference, London: RoutledgeFalmer.

Day, C., Harris, A. and Hadfield, M. (2001) 'Challenging the orthodoxy of effective school leadership', International Journal of Leadership in Education, 4 (1): 39-56.

Day, C., Sammons, P., Hopkins, D., Harris, A., Leithwood, K., Qing, G., Penlington, C., Melta, P., and Kington, A. (2007) The Impact of School Leadership on Pupil Outcomes: Interim Report, Research Report DCSF-RR018, Nottingham: University of Nottingham.

Demertzi, V., Bagakis, G. and Georgiadou, S. (2009) 'School voices in leadership for learning within the Greek context', International Journal of Leadership in Education, 12(3): 297-309.

Department for Education (DfE) (2010) The Importance of Teaching: Schools White Paper, London: The Stationery Office (online).

Department for Education (2010) School Performance Tables: Secondary School GCSE (and equivalent)- The Tables (online). Available at:

http://www.education.gov.uk/schools/performance/archive/schools 10.shtml

Dimmock, C. (2012) Leadership, Capacity Building and School Improvement: Concepts, Themes and Impact, London: Routledge.

Dimmock, C. and Walker, A. (1998) 'Comparative educational administration: developing a cross-cultural conceptual framework', Educational Administration Quarterly, 34(4), 558-595.

Dimmock, C. and Walker, A. (2000) 'Developing comparative and international education leadership and management: a cross-cultural model', School Leadership \& Management, 20(2): 143-160.

Earley, P., Evans, J., Collarbone, P., Gold, A. and Halpin, D. (2002) Establishing the Current State of School Leadership in England, London: Institute of Education, University of London (Research Report No 336).

Educational Law 1304/82 Scientific- Pedagogical Guidance and Management in General Education and Technical- Vocational Education, Paper 144/ 7-121982 Hellenic Republic (online) (in Greek).

Educational Law 2525/97 Comprehensive Upper Secondary School, Entrance of Student Candidates in Tertiary Education; The Evaluation of The Educational Professional Work, FEK 188/ 23-9-1997 Hellenic Republic (online) (in Greek).

Elmore, R. (2000) Building a New Structure for School Leadership, Washington, DC: Albert Shanker Institute.

Ferreira, E. J., Erasmus, A. W. and Groenewald, D. (2009) Administrative Management, Cape Town: Juta \& Company Ltd.

Fitzgerald, T. (2007) 'Documents and documentary analysis: reading between the lines', in A. Briggs and M. Coleman (eds), Research Methods in Educational Leadership and Management, 2nd edn., London: Sage, 278-294. 
Fitzgerald, T. and Gunter, H. M. (2011) 'Dancing to a new tune? Centralisation and decentralisation in educational administration', Journal of Educational Administration and History, 43(2): 89-93.

Gravani, M. N. and John, P. D. (2005) ' 'Them and us': Teachers' and tutors' experiences of a 'new' professional development course in Greece', Compare: A Journal of Comparative and International Education, 35(3): 303-319.

Hallinger, P. (2009) Leadership for 21st Century School: From Instructional Leadership to Leadership for Learning, Hong Kong: The Hong Kong Institute of Education (online).

Hallinger, P. and Heck, R. H. (1996) 'Reassessing the principal's role in school effectiveness: a review of empirical research: 1980-1995', Educational Administration Quarterly, 32(1): 5-44.

Hallinger, P. and Heck, R. H. (1997) 'Exploring the principal's contribution to school effectiveness', School Effectiveness and School Improvement, 8(4): 1-35.

Hallinger, P. and Heck R. H. (2010) 'Leadership for learning: does collaborative leadership make a difference in school improvement?', Educational Management Administration \& Leadership, 38 (6): 654-678.

Hallinger, P. and Heck, R. H. (2011) 'Exploring the journey of school improvement: classifying and analyzing patterns of change in school improvement processes and learning outcomes', School Effectiveness and School Improvement, 22(1): $1-27$.

Hallinger, P. and Lee, M. (2014) 'Mapping instructional leadership in Thailand: Has education reform impacted principal practice?', Educational Management Administration \& Leadership, 42(1): 6-29.

Hallinger, P. and Murphy, J. (1985) 'Assessing the instructional management behavior of principals', The Elementary School Journal, 86(2): 217-247.

Hallinger, P. and Murphy, J. (1986) 'Instructional leadership in effective schools', Educational Resources Information Center (ERIC).

Higham, R., Hopkins, D. and Ahtaridou, E. (2007) 'Improving school leadership: country background report for England', Report for the Department for Children, Schools and Families for the OECD Activity Improving School Leadership Education and Training Policy Division (online).

Hopkins, D., Harris, A. and Jackson, D. (1997) 'Understanding the school's capacity for development', School Leadership and Management, 17(3): 401-411.

Kaparou, M. and Bush, T. (2007) 'Invisible barriers: the career progress of women secondary school principals in Greece', Compare, 37 (2), 221-237.

Kaparou, M. and Bush, T. (2015) 'Instructional leadership in centralised systems: evidence from Greek high-performing secondary schools', School Leadership \& Management, 35(3): 321-345.

Lainas, A. (2004) 'The principal's role and its contribution to school effectiveness', Epistimoniki Epetirida Pedagogikou Tmimatos D.E., 17: 151-179 (in Greek).

Leithwood, K. and Jantzi, D. (2008) 'Linking leadership to student learning: the contributions of leader efficacy', Educational Administration Quarterly, 44(4): 496-528.

Leithwood, K., Jantzi, D. and Steinbach, R. (1999) Changing Leadership for Changing Times, Buckingham: Open University Press.

Leithwood, K. and Montgomery, D. (1982) 'The role of the elementary principal in program improvement', Review of Educational Research, 52(3): 309-339.

Leithwood, K. and Riehl, C. (2003) What Do We Already Know About Successful School Leadership?, Paper prepared for the AERA Division A Task Force for 
the Development of An Agenda for Future Research on Educational Leadership (online).

Leithwood, K., Day, C., Sammons, P., Harris, A. and Hopkins, D. (2006) Seven Strong Claims about Successful School Leadership, Nottingham: National College for School Leadership (NCSL) (online).

Leadership Improvement for Student Achievement (LISA) (2009) The Leadership Cocktail: A Highly Contextual Mix, Project funded by the Education, Audiovisual \& Culture Executive Agency of the EU, The Netherlands.

MacBeath, J. (2006) 'A story of change: growing leadership for learning', Journal of Educational Change, 7(1): 33-46.

MacBeath, J. and Swaffield, S. (2008) 'Leadership for learning: a matter of principle', paper presented at the 21st International Congress for School Effectiveness and Improvement, The Leadership for Learning (Carpe Vitam) Project: The Legacy, Auckland, New Zealand, 6th-9th January 2008.

MacBeath, J. and Townsend, T. (2011) 'Leadership and learning: paradox, paradigms and principles', in T. Townsend and J. MacBeath (eds), International Handbook of Leadership for Learning, London: Springer International Handbooks of Education, 1-25.

Macfarlane, R. and Woods, D. (2010) Going for Great, London: London Leadership Strategy supported by the National College for Leadership of Schools and Children's Services.

Macfarlane, R. and Woods, D. (2011) Glimpses of Greatness, London: London Leadership Strategy supported by the National College for Leadership of Schools and Children's Services.

Marcoulides, G.A. and Heck, R.H. (1992) 'Assessing instructional leadership effectiveness with " $G$ ” theory', International Journal of Educational Management, 6(3): 4-13.

Marks, H. M. and Printy, S. M. (2003) 'Principal leadership and school performance: an integration of transformational and instructional leadership', Educational Administration Quarterly, 39(3): 370-397.

Ministerial Decision 353.1/324/105657/A1/2002 (FEK 1340B/16-10-2002) Specifications of the Directors of the Regional Bureaus for primary and secondary education, headteachers and deputy heads of schools and SEK and school teachers' association responsibilities (online) (in Greek).

Møller, J. (2009) 'Learning to share: a vision of leadership practice', International Journal of Leadership in Education, 12(3): 253-267.

Muijs, D. (2011) 'Researching leadership: towards a new paradigm', in T. Townsend and J. MacBeath (eds), International Handbook of Leadership for Learning, London: Springer International Handbooks of Education, 115-125.

National College for School Leadership (NCSL) (2004) Learning to Lead: NCSL's Strategy for Leadership Learning, Nottingham: NCSL (online).

Organisation for Economic Co-operation and Development (OECD) (2005) Improving School Leadership: Rationale and Plans for the Activity, Meeting of National Representatives, Paris (online).

Organisation for Economic Co-operation and Development (OECD) (2009) Creating Effective Teaching and Learning Environments: First Results from TALIS (online).

Office for Standards in Education (Ofsted) (2009) Twelve Outstanding Secondary Schools: Excelling Against the Odds, London: The Office for Standards in Education, Children's Services and Skills. 
Pashiardis, P. and Pashiardis, G. (2000) Effective Schools: Reality of Utopia?, Athens: Typothito (in Greek).

Pashiardis, P. and Savvides, V. (2011) 'The interplay between instructional and entrepreneurial leadership styles in Cyprus rural primary schools', Leadership and Policy in School, 10(4): 412-427.

Pashiardis, P., Savvides, V., Lytra, E. and Angelidou, K. (2011) 'Successful school leadership in rural contexts: the case of Cyprus', Educational Management Administration \& Leadership, 39(5): 536-553.

Perakyla, A. (2008) 'Analyzing talk and text' in N. K. Denzin and Y. S. Lincoln (eds), Collecting and Interpreting Qualitative Materials, London: Sage, 351374.

Printy, S. M. (2008) 'Leadership for teacher learning: a community of practice perspective', Educational Administration Quarterly, 44(2): 187-226.

Robinson, V. M. J., Lloyd, C. A. and Rowe, K. J. (2008) 'The impact of leadership on student outcomes: an analysis of the different effects of leadership types', Educational Administration Quarterly, 44(5): 635-674.

Rui, Y. (2007) 'Comparing policies', in M. Bray, A. Bob and M. Mason (eds), Comparative Education Research: Approaches and Methods, Comparative Education Research Centre, The University of Hong Kong: Springer.

Saitis, C. and Eliophotou- Menon, M. (2004) 'Views of future and current teachers on the effectiveness of primary school leadership: evidence from Greece', Leadership and Policy in Schools, 3(2): 135-157.

Sammons, P., Gu, Q., Day, C. and Ko, J. (2011) 'Exploring the impact of school leadership on pupil outcomes: results from a study of academically improved and effective schools in England', International Journal of Educational Management, 25(1): 83-101.

Southworth, G. (2002) 'Instructional leadership in schools: reflections and empirical evidence', School Leadership \& Management, 22(1): 73-91.

Spillane, J. P. and Diamond, J. B. (2007) 'Taking a distributed perspective', in J. P. Spillane and J. B. Diamond (eds), Distributed Leadership in Practice, New York: Teachers College, Columbia University, 1-15.

Stravakou, P. (2003) The School Principal in Primary and Secondary Education: Theoretical Analysis and Empirical Research, Thessaloniki: Kyriakides (in Greek).

Swaffield, S. and MacBeath, J. (2009) Researching leadership for learning across international and methodological boundaries, Annual Meeting of the American Educational Research Association, San Diego (online).

Timperley, H. (2006) 'Learning challenges involved in developing leading for learning', Educational Management Administration and Leadership, 34(4): 546-563.

Vygotsky, L.S. (1978) Mind in Society: The Development of Higher Psychological Processes, Cambridge, MA: Harvard University Press (online).

Walker, A. and Dimmock, C. (2002) 'Cross-cultural and comparative insights into educational administration and leadership: an initial framework', in A. Walker and C. Dimmock (eds), School Leadership and Administration: Adopting a Cultural Perspective, London: Routledge, 13-32.

Yin, R. K. (2009) Case Study Research: Design and Methods, 4th edn., London: Sage. 